\title{
A NEOLIBERALIZAÇÃO DA NATUREZA NA FRONTEIRA AGRÍCOLA DO CERRADO NORDESTINO ${ }^{1}$
}

\author{
Eve Anne Bühler ${ }^{2}$ \\ Valter Lúcio de Oliveira ${ }^{3}$
}

\begin{abstract}
RESUMO
Esse artigo busca interrogar, a partir de uma análise dos dispositivos públicos de regulação fundiária e ambiental, além de levantamentos realizados localmente, os processos de apropriação e mercantilização da natureza pelo setor agropecuário na fronteira agrícola do Cerrado nordestino. Em um contexto marcado pela consolidação das lógicas de mercado nos espaços rurais, no gerenciamento das propriedades agrícolas e na regulação ambiental, as abordagens em termos de « neoliberalização » fornecem um quadro teórico pertinente.
\end{abstract}

Palavras-chave: Cerrado, Neoliberalização, Mercantilização Da Natureza, Agronegócio, Fronteira Agrícola.

\section{THE NEOLIBERALIZATION OF NATURE ON THE AGRICULTURAL FRONTIER OF THE NORTHEASTERN CERRADO}

\begin{abstract}
Based on an analysis of public policies regarding land and environmental regulation, as well as locally conducted surveys, this article interrogates the processes by which nature is appropriated and commercialized by agrarian sectors on the agricultural frontier of the Northeastern Cerrado. In a context marked by the consolidation of market logic in rural areas, in farm management and in environmental regulation, approaches in terms of «neoliberalization » provide a relevant theoretical framework.
\end{abstract}

Keywords: Cerrado, Neoliberalization, Nature Commodification, Agribusiness, Agricultural Frontier.

\section{INTRODUÇÃO}

Sabe-se que a matriz econômica brasileira é historicamente dependente e assentada no setor primário, particularmente as commodities agrícolas, o que o eleva a um papel decisivo nos resultados da balança comercial e, por consequência, à busca por constantes aumentos na produção. Isso se faz a partir do expressivo ganho de produtividade verificado nos últimos trinta anos, mas também a partir da ampliação das superfícies dedicadas à agropecuária nas fronteiras agrícolas do país. No entanto, esse processo não se concretiza sem conflitos e tensões, o que faz deste modelo

\footnotetext{
${ }^{1}$ Este artigo é uma tradução livre, com algumas alterações, do artigo Néolibéralisation de la nature sur la frontière agricole du Cerrado nordestin, publicado na Revista Brésil(s) n. 13, 2018. Os autores agradecem o apoio recebido a partir do programa Capes-Cofecub Projeto « Capital financier, appropriation de terres et production agricole moderne » e do CNPq, Edital Humanidades, projeto « Diversidade socioeconômica e estratégias de territorialização dos grandes produtores agrícolas no oeste da Bahia ». Os autores agradecem, ainda, à revista Brésil(s), por ter autorizado uma publicação traduzida do artigo original.

${ }^{2}$ Eve-Anne Bühler é professora do Departamento de Geografia e do Programa de Pós Graduação em Geografia da Universidade Federal do Rio de Janeiro (UFRJ), É membro dos Grupos de Pesquisa REAGRI - CNPq (Rede de Pesquisa sobre as Regiões Agrícolas) e FRONTEIRAS - CNPq. E-mail: eve.buhler@gmail.com

${ }^{3}$ Valter Lúcio de Oliveira é professor do Departamento de Sociologia e Metodologia das Ciências Sociais e dos Programas de Pós-Graduação em Sociologia e Sociologia e Direito da Universidade Federal Fluminense (UFF). É membro do Grupo de Pesquisa FRONTEIRAS - CNPq. E-mail: valteroliveira@id.uff.br
} 
produtivo, social e territorial um alvo de vigorosas críticas. Quando estas críticas são realizadas por Organizações Não Governamentais (ONGs) e outras instituições internacionais, o foco é, na maior parte das vezes, a transformação da floresta amazônica em terras agrícolas, fazendo com que as ameaças a este bioma e seus habitantes ganhe centralidade na luta contra as mudanças ambientais globais. Mais recentemente, a tomada de consciência de que o Cerrado brasileiro também enfrenta problemas semelhantes, apesar de sua colonização agrícola ter se iniciado ainda no começo da década de $1970^{4}$, coincide com a mudança em relação ao antigo discurso de depreciação de tal bioma. Ao contrário do que ocorreu na Amazônia, que suscita há muito tempo uma mobilização internacional, o uso do Cerrado para a agricultura só tardiamente chamou atenção dos atores ambientais. Sua progressiva ocupação por uma agricultura intensiva e moderna, realizada em grande parte por colonos vindos do Sul ou de regiões agrícolas já consolidadas, foi majoritariamente percebida como favorável ao desenvolvimento, mesmo que muitas vezes tenha sido feita fora dos quadros legais, tanto no que se refere à propriedade da terra, quanto em termos ambientais.

Essas dinâmicas podem ser analisadas à luz dos debates teóricos em torno da neoliberalização da natureza e do espaço rural, através da investigação dos processos sucessivos pelos quais a natureza se torna mercadoria e projeta internacionalmente uma região que até então era periférica na economia mundial das commodities agrícolas. Uma especificidade das 'fronteiras' agrícolas brasileiras é que a apropriação e a exploração da natureza são ainda realizadas predominantemente de maneira ilegal. A tolerância dos poderes públicos é, num primeiro momento, conveniente aos interesses dos colonos, mas, posteriormente, sua condição jurídica obscura pode se converter em empecilho no que tange ao acesso aos mercados e às transações comerciais. É esta questão que será analisada neste artigo, isto é, será discutido a maneira pela qual os dispositivos construídos para regular a atividade agrícola conduzem finalmente a legitimar os desmatamentos e a regularizar a apropriação das terras, consolidando e formalizando uma dinâmica de mercado.

Neste sentido, este artigo buscará expor o que deve ser entendido por 'neoliberalização dos espaços rurais', para então, através desta perspectiva, analisar a colonização agrícola do Cerrado. O trabalho destacará a maneira como o processo de colonização agrícola e apropriação fundiária que por vezes é ilegal, tornou-se aceitável pelo mercado. Ver-se-á como, a partir da produção do fato consumado, os atores públicos e privados agem de forma concertada para não colocar em risco aquilo que já existe, buscando apenas dotá-lo de uma segurança jurídica exigida pelos agentes econômicos. A partir de pesquisa empírica realizada na ocasião da promulgação da reforma do

\footnotetext{
${ }^{4}$ Grandes programas de desenvolvimento regional tiveram um papel importante na colonização do Cerrado. Este é o caso do Programa de Cooperação Nipo-Brasileiro para o Desenvolvimento dos Cerrados - PRODECER, em 1974, do Programa para o Desenvolvimento dos Cerrados - POLOCENTRO, em 1975. Para mais detalhes ver Bühler; Oliveira (2013).
} 
código florestal e da lei da regularização fundiária no Estado do Piauí, será mostrado como estas legislações são igualmente destinadas a enquadrar o setor agrícola e a legitimar o fato consumado em benefício dos exploradores mais poderosos e da expansão da economia de mercado.

O material empírico constituiu-se de documentos e entrevistas obtidos em trabalhos de campo realizados entre 2012 e 2016 nos municípios do extremo oeste baiano (Barreiras, Luís Eduardo Magalhães, Correntina, São Desidério e Formosa do Rio Preto) e do sul do Piauí (Bom Jesus e Uruçuí). Cerca de sessenta entrevistas foram realizadas com atores do setor agrícola (produtores agrícolas, prestadores de serviços e fornecedores de maquinários e insumos voltados à produção agrícola, sindicatos e agentes imobiliários) e de instituições públicas.

\section{A NEOLIBERALIZAÇÃO DA NATUREZA E DOS ESPAÇOS RURAIS}

O neoliberalismo é definido por Freitas, Marston e Bakker $(2015,240)$ como "um ideal que expressa um projeto utópico de reorganização do capitalismo em múltiplas escalas [...] através da lógica e do ethos do mercado", cujas manifestações atingem diferentes esferas da vida social. Ação e pensamento neste âmbito estão associados graças a uma construção teórica sofisticada que, sob um manto de objetividade, de lógica e de eficiência, sustenta também interesses econômicos e sociais particulares para tentar protegê-los. No plano econômico, seu caráter polimórfico é frequentemente destacado, mas ele se distingue por apresentar estratégias de acumulação de capital mais intensas que outrora (Brenner, Peck \& Theodore 2010).

O neoliberalismo, assim definido, é raramente observado na sua completude. Nesse sentido, a noção de 'neoliberalização' possui um maior alcance heurístico, na medida em que faz referência aos processos e às manifestações sociais que levam a esse estado final. Esta noção se centra nas ações e no seu controle, bem como nos discursos através dos quais o neoliberalismo se legitima. A neoliberalização deve ser compreendida simultaneamente como um modo disciplinar de regulação e como um regime de acumulação (Bakker, 2010) que redefine as significações e usos do espaço ou dos recursos. Enquanto projeto político, ela visa assegurar as condições de acumulação do capital e preservar o poder das elites em múltiplas escalas. Sua ascendência supõe a elaboração de estratégias que garantam a realização de um lucro pela apropriação, o controle, a transformação e a exploração ou a mercantilização de bens cuja qualidade de recursos se consolida ao longo do processo. $\mathrm{O}$ conjunto se apoia sobre a difusão de um discurso que busca legitimar o neoliberalismo.

Nem homogênea, nem unívoca, a neoliberalização é um mosaico constituído por um conjunto de fenômenos diversos que convergem de maneira mais ou menos recorrente. As experiências do neoliberalismo não são nem completamente idênticas, nem completamente diferentes umas das outras; mas refletem as trajetórias locais, as instituições herdadas e as dinâmicas de regulação em escalas múltiplas. Nesse sentido, Bakker (2010) elaborou uma tipologia 
de processos advindos da neoliberalização e que se aplicam à natureza, como a privatização, a mercantilização, a desregulação e a re-regulação em favor dos interesses econômicos dominantes, a externalização dos custos sociais e ambientais ou, ainda, o reescalonamento da governança, aos quais pode-se adicionar a exploração dos 'fixos' sociais ou ecológicos ${ }^{5}$ (Freitas, Marston \& Bakker, 2015).

Freitas, Marston et Bakker (2015) sublinharam as ambiguidades e as contradições dos discursos e políticas públicas nos países da América Latina que passaram pela onda rosa dos anos 2000. Esses governos assumiram orientações autodesignadas como pós-neoliberais, o que sinalizou o retorno do Estado nos assuntos econômicos e na gestão do território. Entretanto, na prática, estes governos não romperam com o modelo neoliberal de governança dos recursos e do meio ambiente. Assim, traços de governança associados aos dois polos ideal-típicos (pós- e neoliberal) poderiam coexistir com arranjos mais polimórficos, denominados pelos autores de 'não-tão-neoliberais' (notquite-neoliberal). Esses modos de governança híbridos e polimórficos variam em função dos domínios de ação concernidos, dos objetos da ação e dos interesses dos atores presentes.

No que tange à regulação dos recursos naturais, o caráter híbrido é também característico de instrumentos que tentam criar um mercado, assim como mecanismos propícios à acumulação de capital em âmbitos nos quais os próprios mercados fracassaram em atribuir um valor monetário à natureza para além daquele associado à sua função produtiva. Nesse caso, as tentativas de mercantilização da natureza não podem ser feitas sem um quadro institucional voluntarista proveniente do Estado e de seu aparelho regulamentador. São híbridas também no sentido de que requerem a atuação efetiva dos atores econômicos.

De fato, é ilusória a criação de um mercado real do meio ambiente no sentido clássico do termo, pois, como salientam Aubertin, Couvert e Flipo (2016), nem as características do mercado, nem a abordagem instrumental da natureza pela sociedade capitalista permitem a plena realização de tal objetivo. Ainda assim, os processos que aproximam a governança do meio ambiente de um enquadramento normativo e interpretativo neoliberal podem provocar mudanças significativas, mesmo que sejam condenados a serem incompletos e imperfeitos. Em todo caso, trata-se de uma interpretação possível de Karen Bakker (2010), quando ela insiste nos aspectos ideais da neoliberalização. Além de sua dimensão prática, esta contribui para modificar os significados, valores e emoções que arbitram a relação com a natureza e, consequentemente, os comportamentos para com ela. Essa reflexão se aproxima da dimensão política do neoliberalismo, que nos lembra que os discursos e os instrumentos de implementação servem, em geral, aos interesses das elites que

\footnotetext{
${ }^{5}$ A noção de 'fixo' ancora-se nas abordagens da economia política e constitui uma extensão do spacial fix de David Harvey a outros domínios. No domínio do social e do ambiental o 'fixo' se aproxima das externalidades, mas supõe a criação de instrumentos e investimentos que permitem absorver o excedente de capital bem como adiar as crises (Ekers; Prudham, 2015; Bakker, 2009).
} 
o defendem, mesmo quando as suas próprias ações estão em desacordo com tal quadro normativo (Freitas, Marston \& Bakker, 2015). Em outros termos, os instrumentos de governança ambiental que se apoiam sobre uma retórica de mercado podem ser defendidos em nome do liberalismo e da eficiência econômica. No entanto, tais instrumentos são também um tipo de arranjo que protege de fato os interesses da elite econômica ao modificar profundamente a forma de pensar e gerir a natureza (Bull \& Aguilar-Stoen, 2015).

Para Brannstrom (2009), a tendência à neoliberalização do meio ambiente na América Latina pode ser observada através dos baixos orçamentos destinados às instituições responsáveis por esse tema, na adoção de mecanismos de mercado para resolver problemas ou ainda na mercantilização (commodificação) dos recursos e na descentralização da tomada de decisão para escalas nacionais inferiores. A ‘convergência das ordens políticas' descrita por Kervan (2005) para a década de 1990 representa uma outra faceta do reescalonamento. Na virada do século XX, tal convergência levou os Estados da região, impulsionados pelas mesmas influências internacionais, a privilegiarem políticas de conservação bastante similares baseadas, na época, na criação de áreas protegidas, frequentemente acompanhadas de montagens institucionais inovadoras e de uma governança descentralizada que dava lugar de destaque às ONGs. Portanto, a mudança de escala foi realizada em dois níveis, ao revelar a influência dos referenciais de gestão ambiental construídos no âmbito das organizações internacionais e ao abrir a gestão das áreas protegidas à participação local.

Em meados dos anos 2000, a responsabilização e o envolvimento dos atores econômicos na gestão ambiental através de medidas de incentivos estavam na ordem do dia. Sem abandonar as políticas de áreas protegidas, o objetivo era controlar uma gama mais ampla de práticas de destruição da natureza e dos lugares em que elas ocorrem, por meio da criação de um interesse econômico na conservação e pela ampliação do seu alcance espacial. Os exemplos mais comuns deste tipo de instrumento são os chamados PSE (Pagamentos por Serviços Ambientais), os mecanismos de compensação ou, ainda, os selos privados e voluntários que certificam o estabelecimento de boas práticas. Ainda que não ocasionem, em geral, uma remuneração direta de quem subscreveu um selo de responsabilidade social e ambiental, estas certificações se inscrevem na lógica de incentivos pois visam, na maior parte das vezes, a consolidar posições comerciais (junto a consumidores finais ou intermediários). Observa-se que, novamente, os instrumentos na moda correspondem aos dogmas internacionais do momento.

Ampliando esta perspectiva, pode-se considerar com Higgins et al. (2014), que o fenômeno da neoliberalização se estende à ruralidade no seu conjunto, pois engaja, sucessivamente, os componentes naturais constituídos em recursos, a sua regulação, a regulação dos produtos de sua procedência e, enfim, seus espaços. Assim, para esses autores, os ataques contra os mecanismos de proteção dos agricultores nos países ocidentais e o formato dos mecanismos da regulação ambiental 
são sintomáticos da neoliberalização. Os dispositivos de apoio à produção, interpretados como barreiras comerciais ou como práticas de dumping e, portanto, denunciadas nos grandes foros de negociação internacionais como distorção da concorrência, tendem a ser substituídos por mecanismos que desvinculam os subsídios agrícolas dos volumes produzidos. Essas mudanças conduzem à mobilização de novos argumentos para justificar a manutenção dos incentivos financeiros, dessa vez orientados pela ótica dos bens públicos e da multifuncionalidade. Na Europa, isso levou à separação dos subsídios da Política Agrícola Comum (PAC) ${ }^{6}$ entre o primeiro pilar, mais diretamente voltado para a dimensão produtiva, e o segundo pilar, dedicado ao desenvolvimento rural e, simultaneamente, a um reforço dos aspectos ambientais e sociais nos diversos dispositivos. No Brasil, os financiamentos acordados no marco do Plano $\mathrm{ABC}^{7}$ em nome da luta contra o aquecimento global podem ser interpretados como um subsídio disfarçado que, além disso, envia um sinal positivo para os foros internacionais. Um estudo mais profundo mostra, de fato, que esse Plano é antes de tudo uma oferta pouco restritiva de créditos subsidiados a produtores que não têm acesso a outros programas de financiamento da produção (Rosa, 2017). Essas evoluções tendem a dar um novo significado ao rural e à atividade agrícola, consolidando um contexto relativamente refratário à ação intervencionista dos Estados sobre a atividade econômica e redirecionando suas ações para outros aspectos, como a conservação da natureza. Uma outra tendência corresponde à possibilidade aberta aos atores privados de se beneficiar economicamente de ações de conservação e de se posicionar no campo ambiental, consolidando seu papel na regulação dos espaços e dos recursos. Essa ideia é desenvolvida por Gautreau et al. (2016), que analisam a participação dos agentes econômicos na definição das normas e leis que regulam a silvicultura em três países sul-americanos, mostrando que os dispositivos dos quais eles participam, ou são pouco constrangedores ou são desviados de suas finalidades.

Nas regiões de fronteira agrícola dominadas pelo agronegócio, os processos de neoliberalização da natureza e do espaço rural são particularmente emblemáticos. O Estado, depois de ter sido o grande promotor da expansão agrícola no Centro-Oeste, através de pesados investimentos no reequilíbrio territorial, na pesquisa, no financiamento à produção e às infraestruturas, reorientou suas estratégias. Sem abandonar completamente os instrumentos usados até então, o Estado vem tentando, desde os anos 1990, transferir uma parte destes aos atores privados. Brenner, Peck e Theodore (2010) sublinham, num contexto mais amplo, que cada Estado se apropria do processo de uma forma particular, influenciados pelas 'regras do jogo' gerais que

\footnotetext{
${ }^{6}$ A PAC se organiza segundo dois pilares. O primeiro (financiado pela União Europeia) agrupa os subsídios diretos e a organização comum do mercado. $\mathrm{O}$ segundo (financiado pela UE e pelos estados membros) concerne às medidas voltadas para o desenvolvimento rural.

${ }^{7}$ O Plano Agricultura de Baixa Emissão de Carbono (ABC) é destinado a reduzir as emissões de carbono na agricultura via adesão voluntária - e recompensada - dos produtores a medidas de mitigação, como a integração agro-silvo-pastoris, a fixação biológica de nitrogênio, a recuperação de pastagens degradadas etc.
} 
transcendem as fronteiras e se impõem como tendenciais, e pelas suas especificidades históricas, territoriais e políticas, que os levam a fazer adaptações, a avançar às escuras e a derrogar a certos princípios. Assim, as fronteiras agrícolas parecem se revestir de características que, em função de sua ambivalência, clamam por procedimentos singulares de neoliberalização. Elas são lugares e momentos privilegiados para criar mercados de recursos naturais. Entretanto, a criação destes mercados é feita sob condições jurídicas turvas, marcadas por relações de dominação frequentemente brutais, pouco propícias à implementação de um mercado dotado de um mínimo de abertura e de transparência. Seguindo os processos em curso nessas regiões, é possível analisar a sucessão de fatos que sustentam a apropriação privada e frequentemente ilegal do Cerrado pelas elites agrárias integradas aos mercados mundiais de matérias-primas. Para tanto, insistir-se-á nos dispositivos elaborados para resolver a ambivalência citada anteriormente.

\section{O ESTADO, O MERCADO E A PROMOÇÃO DA FRONTEIRA AGRÍCOLA NO CERRADO NORDESTINO}

Através do financiamento à pesquisa agronômica e da criação de uma unidade da Empresa Brasileira de Pesquisa Agropecuária (Embrapa - Cerrado $^{8}$ ), bem como através de financiamentos à produção e da aposta nas matérias-primas para gerar divisas e abastecer os cofres públicos, o Estado não somente deixou acontecer, mas também incentivou o avanço agrícola sobre o território nacional. A complacência em relação aos desmatamentos fraudulentos e a elevação dos preços das matériasprimas na década de 2000 fizeram o resto. A política econômica dos anos Lula amparou essas orientações ao subscrever a passagem do Consenso de Washington ao "Consenso das Commodities" (Svampa, 2012). Essa expressão designa um novo contrato social que emergiu nos países latinoamericanos de centro-esquerda nos anos 2000. Aproveitando os preços excepcionalmente elevados nos mercados de matérias-primas, os governos se engajaram em uma re-primarização de suas economias e de suas exportações, apostando em uma demanda mundial crescente. Contrariamente ao extrativismo histórico, os benefícios acumulados foram parcialmente utilizados nos programas de redistribuição social, permitindo a contenção das desigualdades, tudo isso ao preço de danos recorrentes ao meio ambiente. Segundo alguns analistas, posicionamentos desse tipo permitiram, junto com outras características, qualificar os governos do PT de 'pós-neoliberais', pois, apesar de um retorno do Estado em alguns domínios, como o financiamento à produção, às infraestruturas e às redes de transporte, houve o desenvolvimento paralelo de alguns aspectos característicos da neoliberalização (Acselrad, 2012).

\footnotetext{
${ }^{8}$ Esta unidade da Embrapa dedica seus esforços às pesquisas de variedades vegetais e técnicas de produção adaptadas à região.
} 
Essa hipótese é sustentada por diversos aspectos convergentes: o papel dos atores privados na pesquisa, o financiamento e a organização de novas cadeias. Assim, a pesquisa privada se desenvolveu consideravelmente e tem um peso cada vez maior sobre as inovações agronômicas, consolidando a sua posição ao lado da Embrapa. Ademais, paralelamente ao retorno acentuado do crédito subsidiado pelo Estado (Leite, 2015), atores privados a montante e a jusante também passaram a atuar nesse setor lucrativo, financiando uma parte crescente das safras com juros ligeiramente inferiores àqueles do mercado bancário (Wesz Jr., 2014). Enfim, os anos 2000 foram aqueles da concentração econômica das empresas do setor situadas em ambos os lados da produção, conferindo uma clara hegemonia às multinacionais. Elas desempenharam um papel importante na viabilização do avanço da produção (Frederico, 2009) e, ao se localizarem na vanguarda das frentes agrícolas para assegurar suas parcelas de mercado, estimulam a progressão espacial da atividade.

Esses espaços de monocultura desenvolvidos sobre a vegetação nativa que criam vastos territórios dominados pelo agronegócio são, para Hecht (2005), zonas de sacrifício articuladas e coordenadas pelos atores das cadeias de valor globais, para responder à demanda dos grandes mercados consumidores mundiais. Se o desmatamento da Amazônia suscitou muitos debates e estudos, o destino do Cerrado, ao contrário, foi definido em meio à grande indiferença até recentemente. Um indicador desse descaso é que sua identificação como bioma data apenas dos anos 2000 (Aubertin; Pinton 2013). A influência conjunta de cientistas e grandes ONGs, na sequência de importantes trabalhos de inventário, de caracterização e de lobbying, contribuiu para criar sua identidade. Colocando em evidência a sua biodiversidade excepcional, esses diferentes atores transformaram o Cerrado em hotspot mundial. Ele também ocupou lugar de destaque no cenário nacional desde as crises hídricas dos últimos anos, pois suas numerosas nascentes, que alimentam as principais bacias hidrográficas do território nacional, o tornaram um espaço chave para o abastecimento de água no país. Assim, sua emergência tardia como bioma não favoreceu a elaboração de instrumentos de proteção adequados. Abrangendo os territórios de onze Estados federativos, incluindo uma parte da Amazônia legal ${ }^{9}$, este bioma agrupa um mosaico de ecossistemas que vão da savana herbácea à savana arborizada, da floresta 'seca' à floresta de galeria, o que, evidentemente, não facilitou sua identificação. É importante mencionar que se trata do segundo maior bioma do país, com uma extensão de $2036400 \mathrm{~km}^{2}$ (Mapa 1).

\footnotetext{
${ }^{9}$ A Amazônia Legal é uma divisão geográfica criada em 1953 para delimitar uma zona elegível aos incentivos ao desenvolvimento voltados para a Amazônia. Ela ocupa uma área de aproximadamente cinco milhões de $\mathrm{km}^{2} \mathrm{em} \mathrm{nove}$ estados.
} 
Mapa 1 - Localização do bioma Cerrado e do MATOPIBA ${ }^{10}$

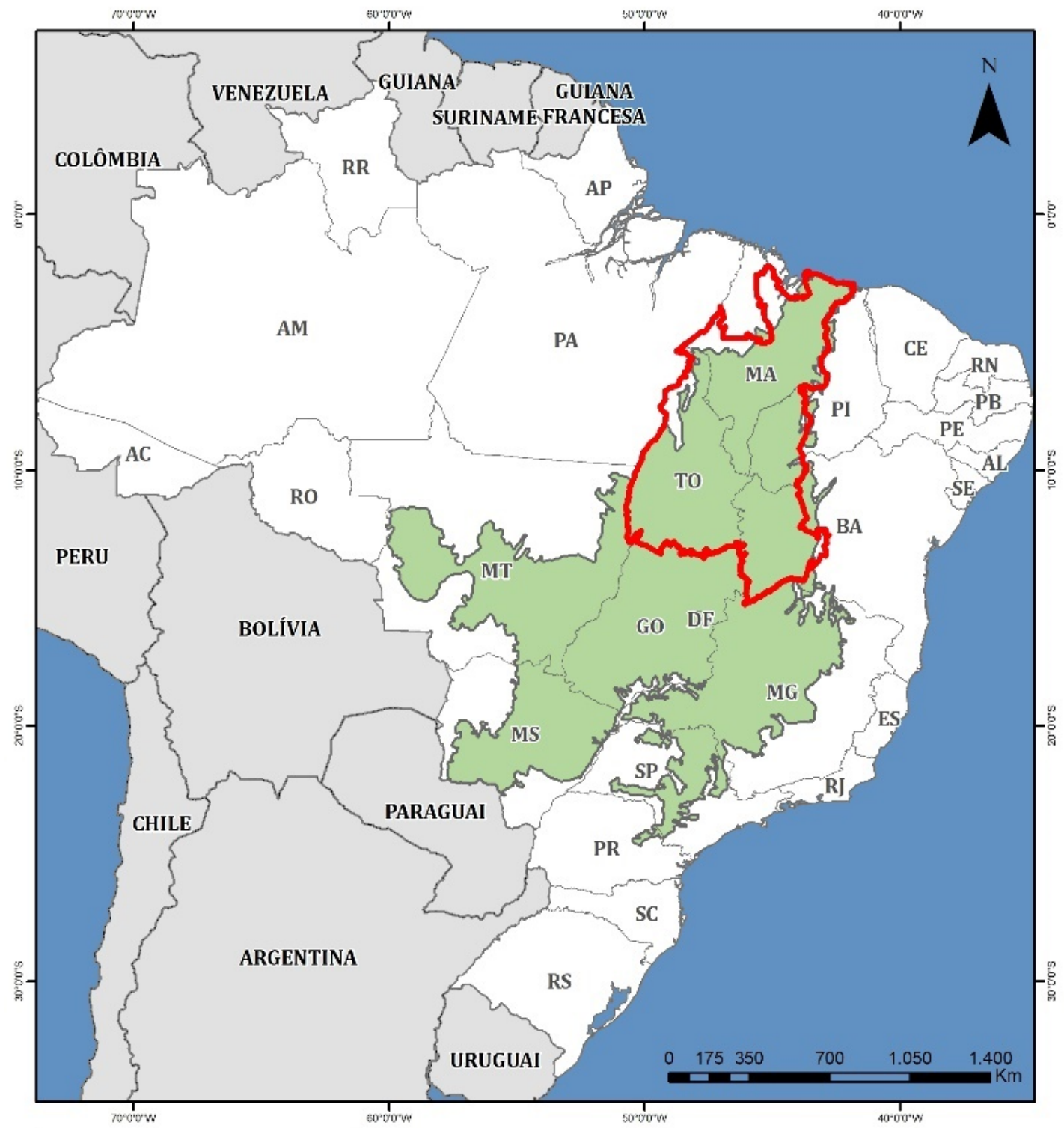

\section{Legenda}

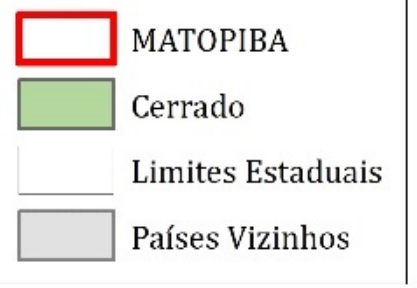

Organização: Pcdro Aguiar Tinoco do Amaral

Fonte: IBGE e Ministério do Meio Ambiente (MMA)

Só tardiamente o Cerrado se beneficiou de um dispositivo de monitoramento e controle do desmatamento comparável àqueles presentes na Amazônia ${ }^{11}$. O Plano de Ação para a Prevenção e Controle do Desmatamento e das Queimadas no Cerrado (PPCerrado) foi criado por decreto

\footnotetext{
${ }^{10}$ O MATOPIBA delimita uma região de rápida expansão agrícola que abrange os quatro estados (Maranhão, Tocantins, Piauí e Bahia), cujas letras iniciais formam o acrônimo.

${ }^{11}$ Como o Projeto de Monitoramento da Floresta Amazônica por Satélites (Prodes) ou o Plano de Ação para Prevenção e Controle do Desmatamento na Amazônia Legal (PPCDAm). Ver: Lhasen, Bustamante \& Dalla-Nora (2016) e Le Tourneau (2015).
} 
presidencial somente em 2010, e seu início efetivo foi adiado diversas vezes. Ele foi concebido como o braço operacional do Programa Cerrado Sustentável (PCS), criado em 2005, cujos objetivos são tão vastos que raramente estiveram providos dos devidos instrumentos de ação. O PPCerrado é responsável pela produção de dados sobre o desmatamento e as queimadas e por medidas de redução desses eventos. Em julho de 2017, o programa publicou estimativas que mostram uma perda anual da cobertura vegetal nativa mais grave no Cerrado do que na Amazônia, apesar de uma diminuição clara desde 2005 (Gráfico 1). Com efeito, para calar a crítica que aumentava frente às taxas de desmatamento recordes no início dos anos 2000, Brasília reforçou os mecanismos de controle e sanção do desmatamento ilegal. O Estado intensificou o monitoramento por satélite e endureceu as sanções contra as infrações. A multa para cada hectare desmatado ilegalmente aumentou de $\mathrm{R} \$ 1.000,00$ para 5.000,00 reais em 2005; a concessão de crédito bancário público foi proibida em 2008 para qualquer propriedade do bioma Amazônia que não fosse regularizada em termos fundiário e ambiental (Le Tourneau, 2015). Apesar dessa tendência a um melhor controle do desmatamento, a perda da vegetação do Cerrado continuou bem maior do que a da Amazônia neste período $^{12}$.

Gráfico 1 - Perda anual da cobertura vegetal nativa na Amazônia Legal e no Cerrado em km²

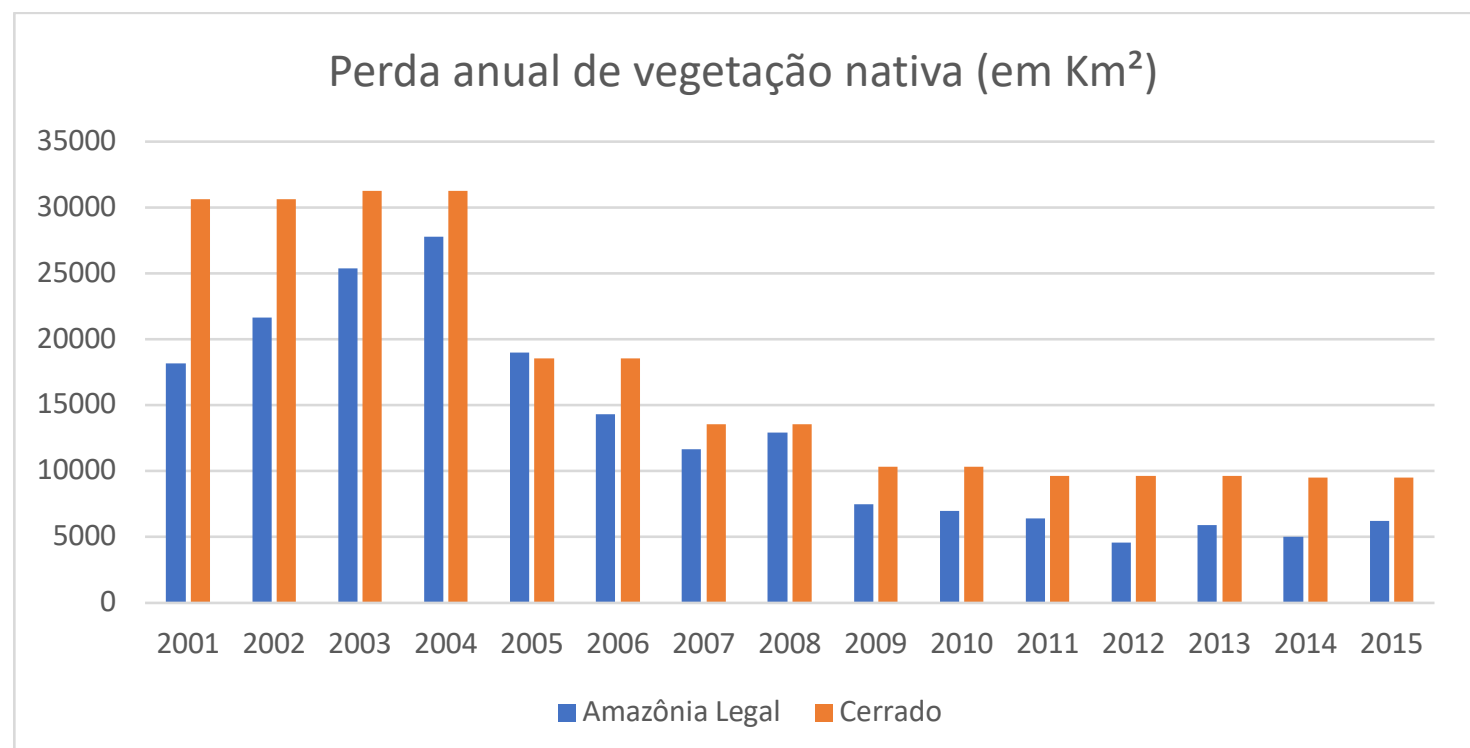

Os valores dos desmatamentos no Cerrado para as séries 2001-2002, 2003-2004, 2005-2006, 2007-2008, 2009-2010, 2011-2013 e 2014-2015 correspondem à média destes períodos.

Fonte: Ministério do Meio Ambiente (2017): http://combateaodesmatamento.mma.gov.br (Acesso em: 23/05/2018).

Nesse contexto, as pesquisas realizadas pelos autores deste artigo foram realizadas nos municípios que ocupam uma posição central na consolidação do agronegócio do Cerrado nordestino,

\footnotetext{
${ }^{12}$ Vale notar que o Golpe de Estado de 2016 marca uma evidente reversão deste quadro, já que todos os indicadores regrediram ao vermelho em apenas dois anos, demonstrando os limites destes mecanismos, cuja utilização depende de uma grande força de vontade política. O peso inédito dos ruralistas no Congresso Federal, bem como internamente ao Executivo, levou a um claro relaxamento da pressão exercida sobre os desmatamentos ilegais.
} 
no coração das novas fronteiras agrícolas. Apesar destes municípios ocuparem lugar de destaque como verdadeiros "celeiros de grãos” emergentes, eles se situam nos Estados da Bahia e do Piauí, que estão entre os mais pobres do Brasil, com Índices de Desenvolvimento Humano (IDH) situados respectivamente na $22^{\mathrm{a}}$ e $25^{\mathrm{a}}$ posições do país (de 26). O Mapa 2 mostra as superfícies da soja no MATOPIBA, considerado como a principal fronteira agrícola desse início de século, e sua evolução entre 2005 e 2015. No mapa também é possível localizar os principais municípios evocados nesse artigo. Pode-se constatar a importância dessa produção no oeste baiano e no sul do Piauí, e até que ponto a dinâmica do crescimento é marcante internamente às margens da zona produtiva. No Piauí, as superfícies semeadas dobraram entre 2005 e 2015. Na Bahia, a soja chegou nos anos 1970 e consolidou progressivamente sua ancoragem na região Oeste. Fora dessas zonas, a produção é quase inexistente nesses Estados.

Mapa 2 - Evolução da produção de soja no MATOPIBA

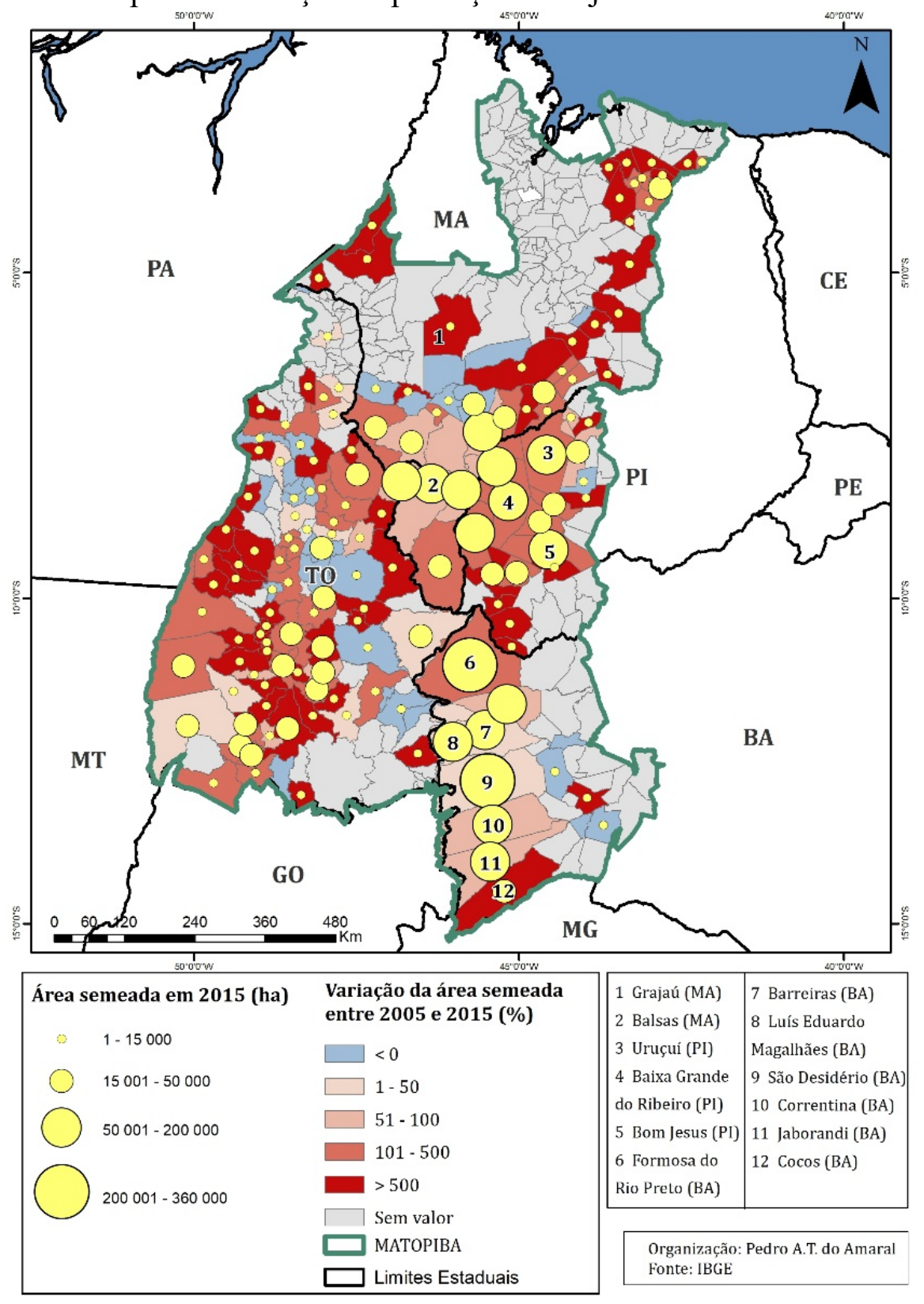


Esses dois Estados são caracterizados por sucessões de clima tropical quente e, em alguns lugares, semiárido, mas as regiões afetadas pelo avanço agrícola se caracterizam por um relevo e uma vegetação particulares. Elas são compostas de planaltos (áreas denominadas 'gerais') de 400 a 900 metros de altitude, propícios à mecanização, cobertos por uma savana arbórea. O clima tropical quente garante precipitações satisfatórias para os cultivos, que vão de 1000 a 1500 mm por ano. Em torno dos planaltos, há áreas povoadas desde o início do século XVII, denominadas de baixões ou terras baixas. São, essencialmente, vales úmidos que formam brejos (ecossistemas com predominância de palmeiras) e asseguram a transição com o semiárido. Parte de seus habitantes se organizou ao redor de latifúndios de criação extensiva de gado e na margem de rios, usando os planaltos para atividades extrativistas de madeira, de coleta (plantas medicinais, frutas), de caça e área de pastagem em tempos de seca. Para essas populações, socialmente e culturalmente muito diversas (Moraes, 2009), os planaltos eram considerados como terras de uso comunitário, independente do seu status jurídico (privado ou público) (Alves 2015). Seus recursos, de livre acesso, eram usados tanto pelas populações camponesas quanto pelos grandes pecuaristas locais. Essas práticas foram pouco perturbadas pelos processos de cercamento que tiveram início ao redor das aglomerações ou pelas tentativas iniciais de exploração comercial em grande escala que surgiram. No Piauí, na década de 1970, o Estado financiou importantes projetos de plantação de frutas (caju) e de modernização da pecuária, sem sucesso (Alves, 2015). Foi nestes mesmos planaltos que o avanço da agricultura se consolidou, a partir dos anos 1990, com uma forte aceleração nos anos 2000, marcada pelo desprezo dos costumes e pelo enfrentamento das resistências das populações camponesas à expulsão de suas terras.

A perda de vegetação nativa atingiu níveis recordes desde o fim dos anos 1990. No oeste da Bahia, somente $40 \%$ da vegetação permaneceu estável entre 1986 e 2005 . Não menos de $12 \%$ da cobertura florestal teria desaparecido, apenas entre 2000 e 2005 (Brannstrom, 2009). Nos anos seguintes, os dados publicados em 2017 pelo Ministério do Meio Ambiente mostram que essas regiões agrícolas ainda são pontos nodais para a expansão agrícola: dentre os 10 municípios do Cerrado que passaram por uma antropização mais forte entre 2013 e 2015, todos estão localizados na região do MATOPIBA, cinco estão no oeste da Bahia e dois no sul do Piauí (tabela 1). Para Brannstrom (2009), fica claro que o oeste da Bahia é uma fronteira agrícola neoliberal: a expansão é motivada pelos mercados globais, ocorrência de políticas de incentivo à exportação, uso determinante de tecnologias de intensificação agrícola, presença de multinacionais e de políticas de privatização fundiária. Tais aspectos também são notáveis para o caso da região dominada pelo agronegócio no Piauí. 
Tabela 1 - Os dez municípios do Cerrado que mais desmataram entre os anos 2013 e 2015

\begin{tabular}{|l|l|c|}
\hline MUNICIPE & ÉTAT & PERTE DE VEGETATION NATURELLE $\left(\mathrm{KM}^{2}\right)$ \\
\hline São Desidério & Bahia & 337,02 \\
\hline Jaborandi & Bahia & 295,27 \\
\hline Formosa do Rio Preto & Bahia & 271,66 \\
\hline Uruçuí & Piauí & 228,65 \\
\hline Balsas & Maranhão & 206,95 \\
\hline Grajaú & Maranhão & 200,01 \\
\hline Baixa Grande do Ribeiro & Piauí & 187,42 \\
\hline Cocos & Bahia & 183,64 \\
\hline Correntina & Bahia & 135,64 \\
\hline Peixe & Tocantins & 135,31 \\
\hline Total & - & 2241 \\
\hline
\end{tabular}

Fonte: Ministério do Meio Ambiente (2017).

\section{A NATUREZA FEITA RECURSO: OS DISCURSOS SOBRE O CERRADO}

A colonização do Cerrado se estabeleceu também com base em um discurso construído pelo meio agrícola e suas instituições, que tentavam requalificar o agronegócio local em atividade eco responsável e construir uma imagem alternativa do Cerrado. Destaca-se que diversas estratégias foram usadas nesse sentido. Na perspectiva dos poderes públicos, a progressão agrícola no Cerrado permitiu que se reorientasse geograficamente o esforço de desenvolvimento regional para fora da Amazônia, calando, assim, a crítica sobre sua ineficácia e seus efeitos ambientais. Um discurso institucional sobre o Cerrado foi, assim, elaborado, investindo na construção de sua 'vocação agrícola' e na sua disponibilidade para fins produtivos (Contini et al., 2010). O interesse ecológico do bioma foi, assim, silenciado, como atesta a fórmula lapidária empregada pelo ministro da Agricultura, Wagner Rossi (2010-2011), acerca do Cerrado nordestino: “Lá, não há nada, só tem Cerrado!" 13 . De maneira mais complexa, observou-se o desenvolvimento de uma retórica contraditória associando natureza e produção, como, por exemplo, nesse argumento que sustentou um projeto da Embrapa para cartografar o uso do solo: "O estudo é considerado estratégico também pela relevância do bioma Cerrados. Trata-se da savana mais rica do mundo em biodiversidade, com uma flora de mais de 12 mil espécies e que nas últimas décadas tornou-se um dos maiores produtores de alimentos do mundo com o suporte de tecnologias adaptadas à região" (Duarte \& Rodrigues, 2015). Assim, mesmo quando as qualidades ecológicas do bioma são reconhecidas, elas parecem contraditoriamente reforçar o projeto agrícola.

Essa concepção é apoiada não somente pelos poderes públicos, mas também pelos agricultores e investidores da região, para os quais a natureza não tem valor intrínseco, já que o seu valor é definido pela produção. Quando indagado sobre as razões da escolha do oeste baiano, um produtor americano, gerente de um pequeno fundo de investimento, começou mencionando a

\footnotetext{
${ }^{13}$ Citado em Camargo (2011).
} 
logística, o ambiente político estável, o solo e o clima que dão flexibilidade na escolha das culturas e tornam a expansão possível. Quando levado a estabelecer uma comparação com a Amazônia e suas frentes pioneiras, ele primeiro enfatizou a falta de transparência no mercado fundiário amazônico, antes de usar um argumento moral de respeito ao bioma: "É sagrado, nós não devemos tocá-lo". Em contraste, a natureza presente no oeste da Bahia é depreciada: "Só tem serpentes e passarinhos, não tem nem macaco... [ele cita outras espécies de animais]. Aqui, os lugares que têm ecossistemas complexos são próximos da água [e, logo, é proibido seu uso para a agricultura intensiva por motivos legais]" (entrevista, 2011).

Esses poucos exemplos mostram até que ponto a concepção de natureza que esses atores manifestam é sobre determinada pela dimensão econômica, reduzindo-a a um recurso produtivo. Isso fica claro num documento prospectivo do ministério da Agricultura: "As áreas que vêm sendo ocupadas nesses estados têm algumas características essenciais para a agricultura moderna. São planas e extensas, solos potencialmente produtivos, disponibilidade de água, e clima propício com dias longos e com elevada intensidade de sol." (Brasil, 2016). A observação do mercado fundiário confirma essa interpretação: a vegetação natural é primeiramente um potencial de produção futura e de lucro. Os dados levantados por Sabai (2015), técnico da Associação de Agricultores e Irrigantes da Bahia (AIBA), revelam que o preço das terras aptas à agricultura de grande escala pode variar de $\mathrm{R} \$ 1.300,00$ reais por hectare até $\mathrm{R} \$ 39.000,00$ reais, de acordo com os índices pluviométricos. Os espaços não desmatados onde chove regularmente são os mais procurados pelos investidores. $\mathrm{O}$ desenvolvimento da região é, consequentemente, avaliado em função do potencial de abertura de novas terras, o que leva a um discurso de atratividade territorial. Para apoiar essa expectativa, a AIBA avalia regularmente, com o apoio de dados quantitativos, as terras ainda 'disponíveis' nos municípios do oeste baiano.

As possibilidades futuras de acumulação e de valorização fundiárias fazem, desta forma, parte integral da avaliação de um bem imobiliário no momento da compra, além de seu potencial agronômico. A natureza não é apenas o suporte material da produção imediata, mas é também uma promessa de lucros posteriores, o que reforça o caráter especulativo do fundiário e a financeirização da agricultura (Fairbairn, 2014; Ouma, 2014). Assim, apesar das aquisições de terras visarem, em parte, a produção, o interesse está também no mercado imobiliário especulativo (Borras et al. 2012). Nesse sentido, quando foi feita a abordagem aos entrevistados desta pesquisa, sobre a questão da abertura de novas terras, estes mostraram pouca preocupação com o impacto de sua atividade sobre os ecossistemas, do mesmo modo que não fizeram considerações de ordem ética sobre a exploração da natureza. Eventualmente, eles passam por essas contradições reafirmando a conformidade de suas unidades produtivas com a legislação, e detalham a adoção de boas práticas, como a gestão 
sustentável dos lixos domésticos e fitossanitários, ou a implementação voluntária de normas ambientais do tipo ISO 14 000, por exemplo.

Mais recentemente, a instauração, a partir do decreto $\mathrm{n}^{\circ} 8447$, de 6 de maio de 2015, do Plano de Desenvolvimento Agropecuário do Matopiba (PDA MATOPIBA), é particularmente eloquente (ver Mapa 1). A criação dessa região institucionaliza a 'vocação agrícola' do Cerrado nordestino e a delimita espacialmente. No seu art. 1, o texto estipula que o programa tem por finalidade "promover e coordenar políticas públicas voltadas ao desenvolvimento econômico sustentável fundado nas atividades agrícolas e pecuárias que resultem na melhoria da qualidade de vida da população" (Brasil, 2015). Os atores agrícolas e seus representantes nos poderes públicos se empenham, assim, em consolidar um discurso eco responsável e desenvolvimentista acerca deste bioma.

\section{REGULARIZAÇÃO AMBIENTAL E FUNDIÁRIA, CHAVES DA MERCANTILIZAÇÃO DA NATUREZA}

Dois eventos analisados nesse artigo contribuíram para a mercantilização do Cerrado e para a evolução dos quadros cognitivos dos atores do setor, sendo eles: a mudança na regulação fundiária no Piauí e, na escala federal, a revisão do Código Florestal. Eles enquadram, por um lado, o acesso à propriedade privada da terra e, de outro, o uso do solo. Para Castree (2003), a mercantilização é um aspecto central da neoliberalização da natureza que passa por alguns processos fundamentais: i) a privatização e a alienação, que conduzem à apropriação privada da natureza e abrem a possibilidade de que ela seja objeto de trocas comerciais, incluindo em seus aspectos aparentemente inalienáveis, como o clima ou o relevo que, uma vez incorporados no mercado fundiário, tornam-se mercadorias; ii) a individuação, que é a capacidade de separar os elementos da natureza de seu contexto, tanto em relação à sua representação mental, quanto fisicamente; iii) a abstração, que permite a formação de categorias suscetíveis de englobar em um mesmo grupo elementos da natureza que, a partir de então, são definidos segundo características padrões reconhecidas pelo mercado; iv) a atribuição de valor, que consiste em restringir as qualidades de um bem ou de um serviço a seu valor monetário para, assim, poder trocá-lo; v) o deslocamento, correspondente à separação do bem de seu vendedor ou de seu comprador.

O novo código florestal e a regularização das propriedades

Fora das áreas protegidas, o principal dispositivo de regulação ambiental das atividades rurais é o Código Florestal. Ele exige, notadamente, uma autorização administrativa antes de qualquer intervenção sobre a vegetação nativa que tenha por objetivo a mudança do uso do solo, assim como impõe a manutenção de ‘Áreas de Preservação Permanente' (APP) sobre os solos mais 
sensíveis à erosão ou sobre aqueles responsáveis pela drenagem. Visa também a conservação de uma parcela da propriedade dedicada à manutenção de vegetação nativa nos espaços agrícolas através da delimitação de uma Reserva Legal (RL), cujas dimensões variam de acordo com os biomas. No Cerrado que se situa fora da Amazônia Legal, a RL é hoje de 20\% da superfície de cada propriedade.

O código florestal em vigor até 2012 datava de 1965, ano no qual foram reforçados alguns mecanismos previstos na primeira lei promulgada em 1934. Devido à falta de recursos financeiros e de controle, o texto nunca havia sido realmente aplicado, pelo menos até o fim dos anos 1990. Em 1996, respondendo às pressões da sociedade civil e da opinião pública, preocupadas com a extensão rápida do desmatamento da Amazônia, o presidente Fernando Henrique Cardoso aumentou a parte obrigatória da RL na Amazônia Legal para 80\% da superfície da propriedade. Dois anos mais tarde, em 1998, foi promulgada a lei dos 'crimes ambientais', que definia sansões penais e administrativa contra infrações de caráter ambiental, ao mesmo tempo que aumentava as multas de acordo com o número de contravenções ao código florestal. Em reação a tais medidas, os principais atores afetados exigiram uma revisão completa do código, que ficou pronta em 1999. Esta não gerou efeitos imediatos, mas constituiu um precedente que ressurgia regularmente desde então (Chiavari; Lopes, 2016). A partir de 2009, as reivindicações em favor de uma modificação da lei reganharam vigor. Depois de longos debates, intensas negociações e campanhas de mobilização dos dois lados, uma reforma do código foi finalmente votada pelo Congresso Nacional, em 2012 (Lei n. ${ }^{\text {o }} 12$ 651/2012). Os protagonistas do processo de revisão foram, de um lado, os ruralistas, tendo à frente a poderosa Confederação Nacional de Agricultura e, do outro, as organizações ambientais. As tensões se cristalizaram em torno de alguns pontos particularmente sensíveis, principalmente aqueles que lidavam com a repressão dos contraventores e os modos de gestão das zonas de RL e de APP.

A medida mais criticada do novo código florestal foi a anistia aos produtores que cometeram irregularidades e promoveram desmatamentos irregulares antes de 2008, sob a condição que esses crimes fossem contrabalanceados por um projeto de recuperação ambiental. Na verdade, o novo texto conservou uma boa parte dos dispositivos previstos em 1965, tornando-os ao mesmo tempo mais flexíveis ou menos coercitivos. Assim, é permitido que eles incluam as áreas dedicadas à APP no cálculo da RL sem condicionalidades, o que antes era restrito às propriedades menores. Da mesma forma, a RL pode ser geograficamente dissociada da propriedade à qual ela pertence, desde que se situe no mesmo bioma e não mais, como antes, na mesma microbacia hidrográfica. Ao criar mecanismos de compensação ${ }^{14}$ e ao autorizar o reflorestamento com espécies exóticas, o código de

\footnotetext{
${ }^{14}$ As flexibilizações e os mecanismos de compensação mais importantes são: 1) a possibilidade de incluir a APP no montante de área destinada a RL, qualquer que seja o tamanho da propriedade; 2) As pequenas propriedades não são
} 
2012 alivia ainda mais as modalidades de recuperação das áreas de RL eliminadas. Também confirma a descentralização iniciada em 2006 com a lei de gestão de florestas públicas que havia transferido a gestão florestal para níveis administrativos inferiores. Ao confiar o Cadastro Ambiental Rural (CAR) ${ }^{15}$ aos Estados, ela reforça o reescalonamento da governança e permite que as tomadas de decisões e o controle de informações ambientais se deem a partir das relações sociais - e de poder - estabelecidas ao nível local. O Estado da Bahia, devido à forte influência de atores agrícolas, apostou bastante na descentralização. Assim, ele se equipou de um dispositivo integrado de informações no Instituto do Meio Ambiente e Recursos Hídricos (INEMA) e dotou-se do seu próprio cadastro, o Cadastro Estadual Florestal de Imóveis Rurais (CEFIR), o qual permite reunir as demandas de autorização de desmatamento com as solicitações de utilização de recursos hídricos. Assim, a conformidade da propriedade com as exigências do código florestal se tornou indispensável para a obtenção de qualquer autorização de natureza ambiental. Campanhas de mobilização e de formação no CAR foram feitas prioritariamente nos espaços de agronegócio (oeste baiano e vale do São Francisco) para convencer os produtores a fazerem suas declarações (INEMA, 2015), graças a cofinanciamentos públicos e privados (Estado, BNDES, AIBA, Fundo Amazônia ${ }^{16}$ etc.,).

Para incitar os produtores a declararem suas propriedades no CEFIR, a principal associação de produtores local, a AIBA cita oito vantagens dessa formalidade, das quais apenas uma manifesta uma real preocupação ambiental (Reis, 2016). As sete outras estão ligadas à segurança jurídica do produtor e ao acesso a políticas públicas, garantidos pela declaração do CEFIR. Os representantes do Estado da Bahia mostraram em outras ocasiões que eles procuram, acima de tudo, simplificar o processo de conformidade dos produtores. Assim, em contradição com os princípios do código florestal, o governador da Bahia adotou dois decretos em 2014 e 2016 (n 15 682/2014 e $n^{\circ} 16$ 963/2016) que dispensam os produtores agrícolas e silvicultores de autorização antes de realizar o desmatamento. Ainda que esses últimos tenham sido suspensos pela Justiça Federal numa decisão liminar de 14 de março de 2017, os dados de antropização mostram a que ponto o período foi marcado por desmatamentos massivos, potencialmente associados a essa flexibilização da legislação.

mais obrigadas a reconstituir a RL desmatada antes de 2008; 3) A RL pode ser compensada por outra área de tamanho idêntico, localizada em outro local, desde que pertencente ao mesmo bioma (enquanto a lei anterior exigia que fosse localizada dentro da mesma Microbacia hidrográfica); 4) Redução, sob certas condições, da largura das APPs protetoras dos recursos hídricos; 5) Criação de um mercado de compensação a partir de títulos emitidos (as CRA) que representam espaços florestais que compensam os desmatamentos em uma unidade produtiva.

${ }^{15}$ O CAR é um cadastro no qual os produtores declaram suas RL e APP e assumem compromissos de regularização, se for o caso. Introduzido no formato atual pela reforma do Código Florestal de 2012, sua elaboração é obrigatória e associada a sanções no caso de não execução. As significativas taxas de respostas permitem realizar uma cartografia fina dos espaços agrícolas com base na autodeclaração.

16 Para maiores detalhes sobre a ação do Fundo Amazônia, ver: http://www.fundoamazonia.gov.br/FundoAmazonia/fam/site_pt/Esquerdo/Projetos_Apoiados/Lista_Projetos/Estado_Ba hia_CAR (consultado em 15/09/2017). 
As primeiras informações publicadas sobre as declarações do CAR mostram, em pequena escala, que as regiões do agronegócio aderiram massivamente ao dispositivo. Mapas elaborados em uma escala maior, com base nos dados públicos das declarações registradas até o dia 30 de junho de 2017, permitem observar a localização das propriedades declarantes (mapas 3 e 4). Essa ampla adesão ilustra um interesse bem claro dos atores agrícolas e a eficácia das campanhas de mobilização feitas por organizações profissionais agrícolas. Cabe observar, também, que a escolha da localização das RL se assemelha de um município a outro: situam-se nos confins das propriedades e, na medida do possível, na borda do planalto, para perturbar o mínimo possível o processo produtivo presente e futuro.

Mapa 3 - Exemplos de localização das reservas legais no município de Correntina - BA

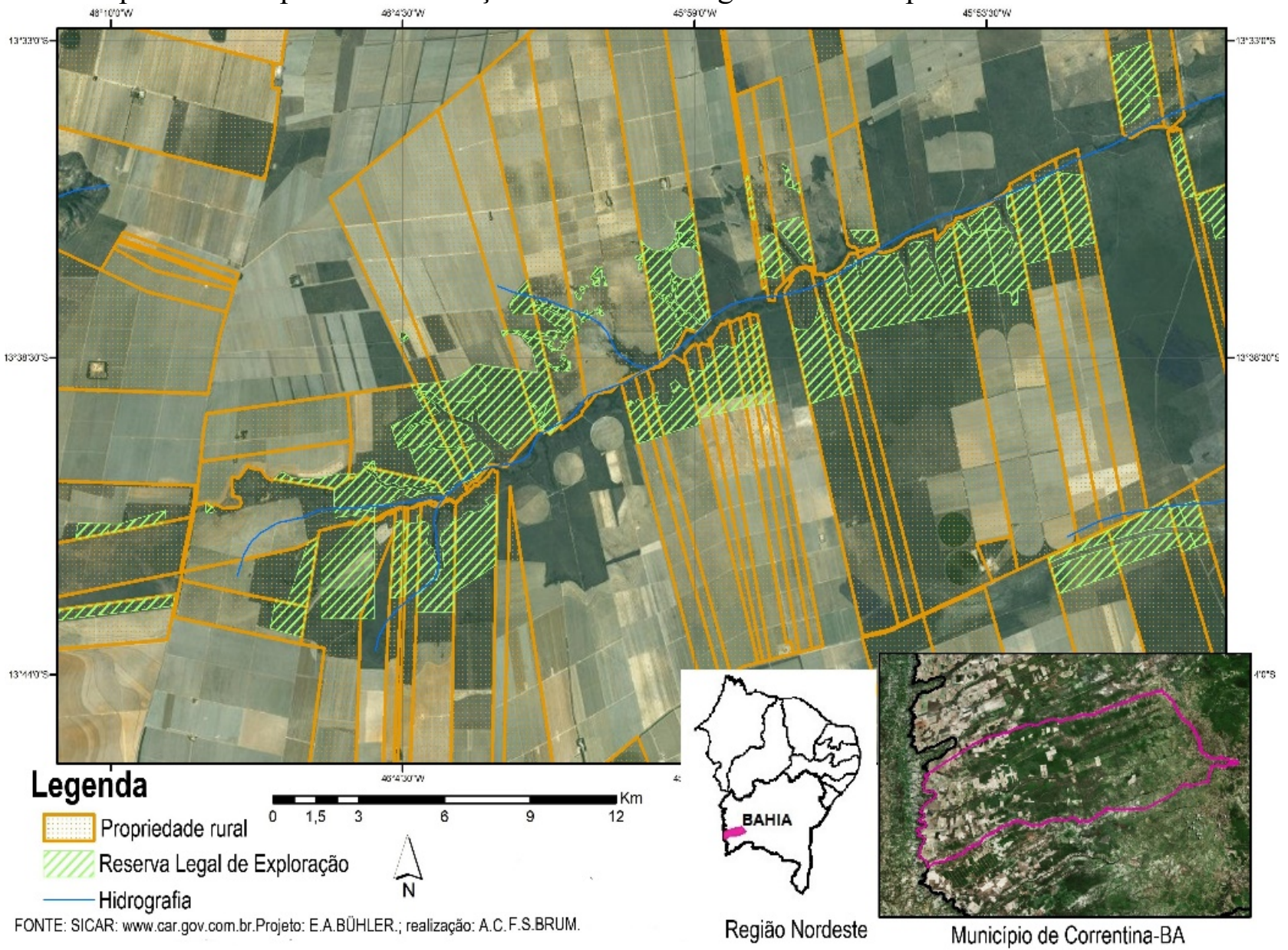




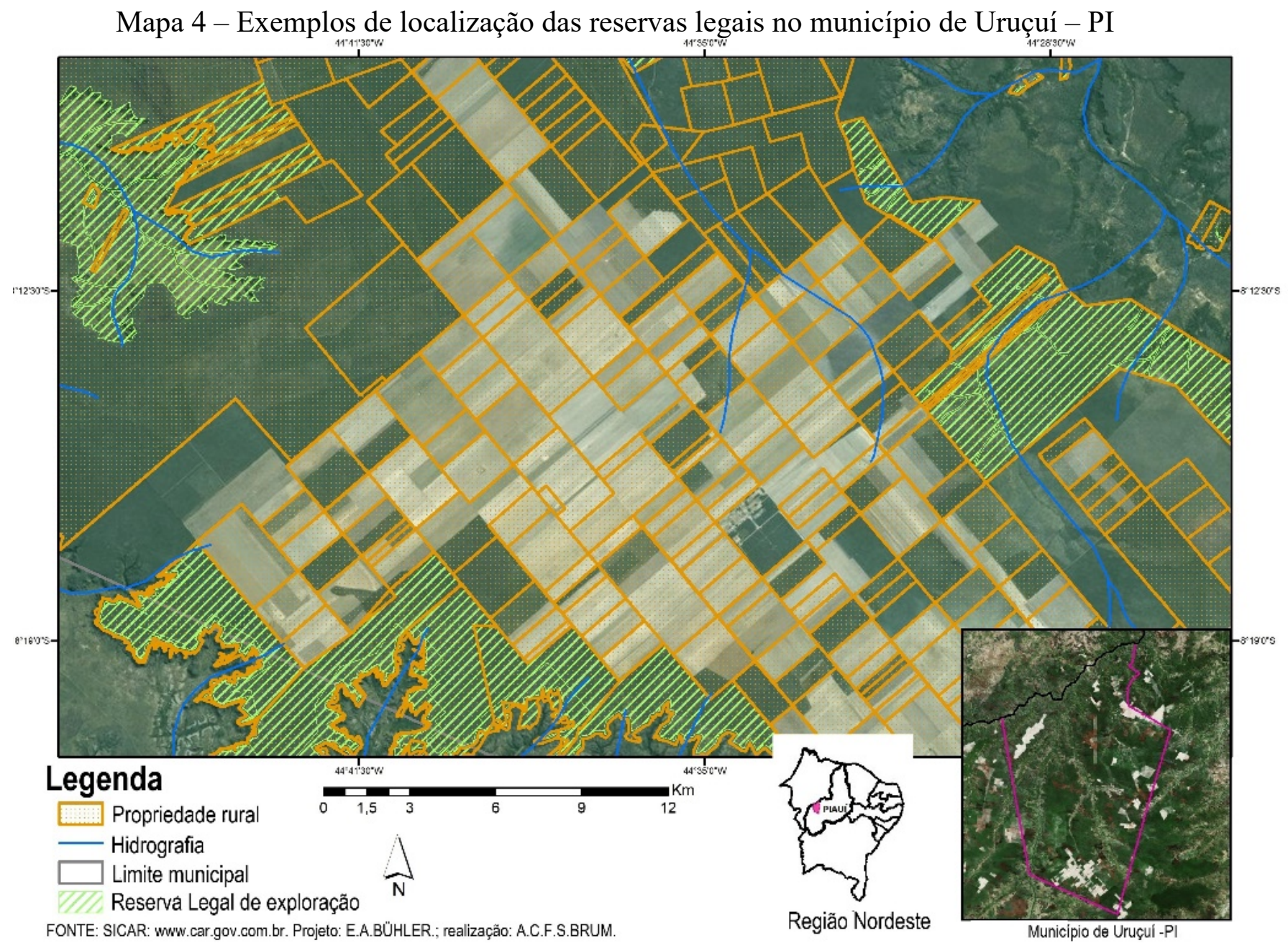

A observação da utilização feita do CAR pelos produtores indica também que ele é muitas vezes um instrumento de legitimação da apropriação ilegal das terras. Estudos e testemunhos mostraram que os produtores conseguem fazer a sua inscrição no CAR mesmo sem o título de propriedade em seu nome, desde que apresentem um conjunto de documentos que tendam a atestar a legitimidade da propriedade do imóvel. Em troca, os interessados usam o certificado de registro no CAR (entre outros documentos) para regularizar a sua situação e obter o status de proprietário (Pires, 2017; Moreira, 2016).

Para além das consequências ambientais de uma lei mais permissiva, o novo código florestal e os dispositivos descentralizados favorecem, deste modo, a exploração e a mercantilização da natureza, mesmo quando ela é ilegal. A reforma do código florestal é fruto de conflitos e relações de poder que revelam até que ponto a instituição estatal é permeável aos interesses dos grupos econômicos. As violações repetidas da lei conduziram a uma reforma que visava fornecer uma segurança jurídica aos produtores em situação irregular. Visto que o mercado impõe restrições às transações cujos contornos jurídicos não são claros, ele pode também criar condições para que o Estado corrija as situações em função das suas necessidades. Este caso não é muito distante daquele 
que vamos analisar agora que, desta vez, diz respeito à formulação das leis que regulam a propriedade de terras no Piaú.

\section{UM MERCADO FUNDIÁRIO AINDA OPACO}

Segundo os técnicos do Instituto de Terras do Piauí (Interpi), organismo responsável pela questão fundiária, as propriedades rurais do Estado que possuem títulos legais definitivos são muito raras. Como afirma o pesquisador de Bom Jesus e agente imobiliário nas horas vagas:

Essa é uma região de muitos problemas. Em 1986 não havia nada desmatado. As datas ${ }^{17}$ eram criadas na parte de baixo onde havia água. Por isso não havia datas no cerrado. $\mathrm{O}$ cerrado passou a valer mais que as áreas baixas e os produtores passaram para a parte de cima, estendendo suas escrituras para as áreas de cerrado (entrevista, 2015).

Os conflitos fundiários podem ter relações com a definição dos limites de uma propriedade, ou mesmo sua superposição total com uma outra. Não é raro que uma mesma terra tenha diversos supostos proprietários e que certos produtores não avisados corram o risco de serem expulsos. De fato, um contrato de compra e venda de uma propriedade, mesmo registrada no cartório, não presume um título formal de propriedade considerado 'legal'. Ainda que a maior parte dos bens imobiliários não seja totalmente legalizada, eles são objeto de transações acompanhadas de um conjunto de documentos que 'tendem' a provar a propriedade e são aceitos pela maioria dos cartórios. Sem título legal definitivo, continuam sendo expostos à contestação ou à usurpação. Para resolver ou evitar essas situações, os profissionais se especializam em operações que visam 'esquentar a documentação': após a verificação dos documentos existentes, eles se empenham em produzir novos documentos ou em conseguir que sejam reconhecidos para, dessa forma, garantir saídas favoráveis em casos duvidosos.

Desde que alguns escândalos emblemáticos os levaram à prudência, os grandes grupos e as empresas financiadas por fundos de investimento tendem a evitar este tipo de risco. Eles encontram meios de se proteger ao aliar o seu capital a atores locais, ou então se amparam em apoios políticos e judiciários sólidos. Estes atores também se beneficiam dos discursos produzidos sobre a região, que ocultam os conflitos e destacam uma fronteira pacífica. A legalidade, no entanto, não é o que se observa com maior frequência, como testemunha a empresa RADAR $^{18}$, que teria comprado terras adquiridas de maneira irregular à ocasião de sua instalação no MATOPIBA e cuja situação fundiária foi denunciada por ONGs (Pitta \& Mendonça 2015), colocando-a sob ameaça de processos judiciais (Romero 2015).

\footnotetext{
${ }^{17}$ Unidade de medida utilizada até 1822 relacionada ao sistema de sesmaria e equivalente a 13.068 ha

${ }^{18}$ Empresa criada pelo grupo Cosan, gigante brasileira do agronegócio e das agroenergias, para gerir propriedades agrícolas. Ela administra unidades produtivas em oito estados brasileiros, perfazendo um total de 280000 ha. Suas ações são, atualmente, partilhadas pela Cosan e um fundo de pensão de professores estadunidenses.
} 
Sob pressão de atores econômicos, o Estado começou um processo de regularização das propriedades situadas em terras públicas que consiste, após analisar um conjunto de documentos, em reconhecer uma ocupação de fato como sendo de direito, desde que seja constatada a 'boa fé' de tais produtores. Esse processo significa, ao fim e ao cabo, a formalização da transferência de terras até então sob o domínio do poder público, para atores privados. Tal ato se concretiza através de uma aquisição formal cujo valor de pagamento ao poder público está bem distante do seu valor de mercado. É dessa forma que ocorre a atribuição de um título legal de propriedade aos agricultores e empresas agrícolas que até então se encontravam na ilegalidade. Portanto, a regularização privatiza bens públicos que foram adquiridos de forma fraudulenta. Os documentos emitidos pelo Estado selam essa transferência, adiam eventuais conflitos e dão um impulso à atratividade da região.

Tanto em matéria ambiental quanto fundiária, os procedimentos de regularização são momentos importantes da estruturação formal de um mercado de bens naturais, e, nas fronteiras agrícolas, as regularizações fundiária e ambiental caminham juntas. É nesse contexto que o Interpi verifica os títulos fundiários e legaliza as propriedades instaladas 'de boa fé' sobre as terras públicas. Dois técnicos do Interpi que trabalham em Teresina, a capital, apresentam o seu trabalho da seguinte maneira:

a meta do INTERPI [é] implementar a regularização fundiária (...) no Piauí todo. [Dar] segurança jurídica aos proprietários visando a ampliação do processo produtivo, a preservação do meio ambiente e o desenvolvimento sustentável. Dar respostas aos processos judiciais. (...) O juiz já está mandando esses processos para cá, que sabe que a gente tá trabalhando na região. (...) Houve a necessidade da gente estar criando o centro de geotecnologia fundiária ambiental com todo o equipamento necessário para gente ter esse banco de dados e o objetivo principal é a gente fazer a regularização fundiária casada com a regularização ambiental, nenhum processo de regularização fundiária pode ser concluído sem que essa área esteja ambientalmente regular. (entrevista, 2016).

Como se percebe, o Estado do Piaú constituiu uma base de dados que associa as informações fundiárias e ambientais visando condicionar qualquer regulação fundiária à obrigação de estar em dia com a legislação ambiental. As instituições públicas agem, deste modo, a serviço das empresas agrícolas quando privatizam as terras públicas a preços baixos e quando trabalham para a reestruturação do mercado fundiário, fomentando para a atratividade territorial. $\mathrm{O}$ representante legal do Interpi é eloquente nesse sentido:

As pessoas às vezes até me criticam dizendo que eu sou um neoliberal, que eu quero vender tudo do estado, mas eu me pergunto uma coisa: o que o estado vai fazer com terra? As terras só têm duas finalidades: edificar e produzir. Fora isso qual é a utilidade da terra? Para mim se o estado está trazendo esses investidores para que esses investidores façam fomentar a economia, ótimo, maravilha, acho que isso é o papel, entendeu? Sabem que as terras são griladas, todas, mas a partir do momento em que cumprem a função social, se regulariza, é uma vontade política em nível de Estado (entrevista, 2016). 
Observa-se, portanto, que a questão fundiária é retomada pelos poderes públicos, visando, neste caso, a estruturação formal do mercado e a estabilização de seus atores. No entanto, os conflitos para o controle da região ainda são numerosos, embora amplamente silenciados pelos produtores que tentam veicular uma imagem do Cerrado sem habitantes e de uma colonização sem conflitos.

\section{A floresta no centro dos conflitos fundiários}

Num contexto de escassez das melhores terras, formulamos a hipótese de que os conflitos agrários se acentuaram ao redor das RL após a reforma do Código Florestal e graças aos caminhos que ele abriu em direção da mercantilização e da exploração da natureza.

A criação das Cotas de Reserva Ambiental (CRA) pelo código de 2012, por exemplo, permite a criação de um mercado de compensação de reservas legais que representam, do ponto de vista econômico, uma terra ociosa e não valorizável. As CRA autorizam os proprietários que assim o desejam a compensar os desmatamentos que excedem o limite legal através da compra de uma servidão ambiental ${ }^{19} \mathrm{em}$ uma área que comporte uma cobertura vegetal 'equivalente' à vegetação nativa suprimida. Inversamente, um proprietário que dispõe de florestas em excedente pode propôlas ao mercado. Mesmo que a efetivação das CRA ainda seja muito caótica e careça de uma regulamentação jurídica específica em escala federal (os decretos de aplicação tardam a chegar), esse dispositivo é uma espécie de carta branca aos produtores que já especulam sobre a futura exploração produtiva de terras atualmente em RL. Eles podem também sentirem-se autorizados a deixar de restaurar a vegetação que foi retirada sem autorização, jogando com o tempo até a completa operacionalização das CRA para, só a partir daí, efetivar a compensação. Ao ampliar a possibilidade de localização possível das reservas legais em outros lugares, de um mesmo bioma e na propriedade de outra pessoa, as CRA autorizam, no fim das contas, os desmatamentos integrais nos espaços agrícolas mais cobiçados, aumentando ainda mais a pressão sobre os recursos nesses lugares. Não por acaso, as CRA representam uma nova oportunidade de negócios e são defendidas pelos interessados como uma necessária modernização da relação entre produção e meio ambiente.

Pesquisas realizadas em 2014 e 2016 no município de Uruçuí mostram uma outra faceta das estratégias que podem ser adotadas, tendo em vista a interface entre as possibilidades abertas com o Novo Código Florestal e os interesses do mercado fundiário. Evidência dessas estratégias se manifestou em um conflito que ocorreu entre colonos provenientes do sul do país, no final dos anos 1990, e um produtor que reivindicava a propriedade de parte da área de RL, estabelecida na forma

\footnotetext{
${ }^{19}$ A servidão ambiental é um ato jurídico vinculante no qual um proprietário fundiário se desfaz voluntariamente de uma parte de seus direitos de usufruto de um bem em benefício de um terceiro. A servidão visa, neste caso, a defesa de características ambientais - aqui, o engajamento a preservar a cobertura florestal ou a vegetação nativa de uma parcela e pode ser concedida a título gratuito ou oneroso.
} 
de condomínio entre vários agricultores. Ou seja, estes agricultores, reunidos em uma associação, optaram por conectar a RL de cada propriedade, configurando uma zona de proteção contínua e bastante extensa. Ao configurar uma área não explorada, a reserva legal desta associação constituíase em um dos últimos espaços ainda não submetidos à produção naquela localidade (ver mapa 4). Ela foi objeto de uma tentativa de desmatamento durante a noite, visando eliminar em tempo recorde a sua vegetação nativa, e simular uma exploração da mesma. O autor de tal operação pretendia criar evidências de que detinha a posse efetiva daquela parcela, cuja propriedade ele reivindicava. A ocupação e a exploração agrícola de facto constituem, frequentemente, as condições iniciais para as reivindicações fundiárias na justiça. Assim, aqueles que pretendem se tornar proprietários lançam mão de tais estratégias, distorcendo a legislação sobre o direito de posse que, em princípio, permite aos agricultores ter acesso à propriedade de terras que eles cultivam de boa-fé. Para os citados colonos, a batalha teve como foco principal a questão fundiária; a questão ambiental ficou secundarizada, pois a perda daquela RL poderia facilmente ser compensada pela compra de uma terra numa região menos valorizada do Cerrado ou por uma futura CRA. Esse episódio ameaçava diretamente o procedimento de regularização fundiária recentemente solicitada pela associação junto ao Interpi. Visto que a área destes colonos havia sido comprada de um dos maiores grileiros do Piauí, eles estavam de fato instalados em terras públicas apropriadas ilegalmente ${ }^{20}$.

Para esses colonos, a perda da RL significava antes de tudo uma interrupção do processo de regularização, pois a dimensão ambiental neste contexto estaria ligada à questão fundiária. No entanto, esse conflito mostra também que, a partir do novo código florestal, as zonas de RL valorizaram-se e tornaram-se novos objetos de conflitos. Elas estão, de fato, localizadas no centro de regiões produtivas em que os estoques fundiários ainda disponíveis para a agricultura de larga escala estão diminuindo. Ao criar oportunidades de lucro nos espaços marginais graças ao deslocamento das RL ou às CRA, o código florestal protege também os interesses dos produtores locais. Nas regiões onde a questão fundiária não está resolvida, pode se acirrar a cobiça por terras ainda não desmatadas, utilizando, para isso, procedimentos típicos das fronteiras agrícolas.

\section{CONCLUSÃO}

A dinâmica de acumulação capitalista exige a incorporação crescente de espaços e de recursos ao processo produtivo. Face à maior sensibilidade ecológica da população e ao apelo global para um melhor controle sobre a destruição da natureza, os agentes do 'desenvolvimento' renovaram suas práticas e seus discursos. O meio ambiente pode ser, a partir de então, mobilizado

\footnotetext{
${ }^{20}$ Segundo um tabelião local, o grileiro que está na origem dessas propriedades constituiu, por diversos procedimentos ilegais, uma propriedade de 35 mil ha que foi revendida em seguida na forma de parcelas que iam de 100 a vários milhares de ha.
} 
tanto para reafirmar a produção pela introdução de uma retórica de sustentabilidade, quanto para questionar esse processo e lhe impor limites. A complexa articulação entre diferentes elementos do discurso e da prática podem conduzir a uma ou outra opção, como ilustra o caso da Amazônia, de um lado, e do Cerrado, de outro.

Tratando-se das fronteiras agrícolas do Cerrado nordestino, sua ocupação está ancorada em processos conflituosos e ilegais de apropriação fundiária e de mudança no uso da natureza. A estratégia dominante, que consiste em submeter as autoridades e os habitantes ao fato consumado da apropriação das terras ou da exploração da natureza, sem preocupações acerca da sua legalidade, implica a conivência do Estado garantida pela presença, em seu seio, de representantes dos agentes econômicos interessados. Com o passar dos anos, e conforme a correlação de forças políticas, os agentes do Estado se veem obrigados a consolidar as irregularidades regularizando-as, seja motivado por um princípio de realidade, por uma falta de vontade política ou, ainda, pelas colusões que mantem.

Esses procedimentos remetem ao que é tratado aqui como um processo de neoliberalização da natureza e do espaço rural que se expressa de diferentes maneiras: discursos sobre a insegurança jurídica ou da necessária modernização das questões fundiárias e ambientais; marketing econômico e político do setor devido ao seu peso econômico nacional; retórica da eficiência tecnológica. A legalização daquilo que foi produzido de maneira irregular é um dos mecanismos deste processo e representa um momento particular da mercantilização da natureza nas fronteiras agrícolas. Ela assegura a passagem de uma apropriação de fato das terras públicas a uma apropriação de direito (legal) das mesmas, derrubando as últimas barreiras à sua plena devoção ao mercado. O que parecia contrário aos princípios elementares do neoliberalismo é, na realidade, o que garante a privatização de acordo com modalidades altamente favoráveis aos atores econômicos e em detrimento do bem público. Trata-se, em última instância, de subverter as regras legais estabelecidas, para produzir uma nova regulação mais pragmática e favorável aos meios agrícolas. O último exemplo desta lógica encontra-se na lei $\mathrm{n}^{\circ} 13465$, de 11 de julho de 2017, que flexibiliza a regularização de terras ilegalmente apropriadas antes de 2011, desta vez na escala federal, e fixa compensações financeiras que podem ser inferiores a $10 \%$ do preço do mercado.

Uma nova gestão pública foi instalada para responder à lógica da eficiência do Estado que, longe de desaparecer, adota comportamentos próprios ao setor privado para responder aos interesses deste último (March, 2013). A presença, no Piauí, do Banco Mundial para apoiar e organizar a regularização fundiária é testemunha disso, assegurando o controle de recursos que antes eram de acesso livre ou de uso coletivo. Assim, as adaptações legais e organizacionais favorecem a privatização da natureza ao passo em que as transformações de ordem institucional (normas, valores), permitem a sua mercantilização. 


\section{REFERÊNCIAS}

ACSELRAD, Vitor. A economia política do agronegócio no Brasil: o legado desenvolvimentista no contexto da democratização com liberalização. Tese de doutorado em Ciencia Política, Rio de Janeiro : IESP-UERJ, 2012.

ALVES, Vincente Lemos. A Formação das condições para a instalação do agronegócio nos cerrados piauienses e as mudanças nas formas de uso da terra dos Gerais. In: A empresa RADAR S/A e a especulação com terras no Brasil. Rede Social de Justiça e Direitos Humanos, dirigido por PITTA, Fabio; MENDONÇA, Maria Luiza. São Paulo: Outras Expressões. 48-55. Disponível em: $<$ http://www.social.org.br/files/pdf/RevistaREDE2015paranet\%202.pdf $>$. Acesso em: 15 mai. 2017

AUBERTIN, Catherine; PINTON, Florence. L'invention du biome Cerrado, Confins, São Paulo/Paris, 17, Mars 2013. Disponível em: <http://confins.revues.org/8218>. ; DOI : 10.4000/confins.8218 (Acesso em: 20 abr. 2014).

AUBERTIN, Catherine; COUVET, Denis; FLIPO, Fabrice. Une « marchandisation de la nature? De l'intégration de la nature en économie. Revue du Mauss, Paris, 9 février 2016.. Disponível em: $<$ https://www.journaldumauss.net/?Une-marchandisation-de-la-nature $>$. Acesso em: 05 jun. 2016.

BAKKER, Karen. Neoliberal nature, ecological fixes, and the pitfalls of comparative research. Environment and Planning A. Manchester, 41, p. 1781-1787, 2009.

BAKKER, Karen. The limits of 'neoliberal natures': Debating green neoliberalism. Progress in Human Geography, Manchester, 34(6), p. 715-735, 2010.

BORRAS, Saturnino, Cristobal KAY, Sergio GOMEZ \& John WILKINSON. Land Grabbing and global capitalist accumulation: key features in Latin America. Canadian Journal of Devlopment Studies/Revue canadienne d'études du développement. Kelowna, Colúmbia Britânica, Canadá, V. 33, n. 4, p. 402-416, 2012.

BRANNSTROM, Christian. South America's Neoliberal Agricultural Frontiers: Places of Environmental Sacrifice or Conservation Opportunity? Ambio: a Journal of the Human Environment. Estocolmo, 38(3), p. 141-149, 2009.

BRASIL. Decreto No 8.447. In: Diário Oficial da União, Brasília, seção 1, p. 85, 2015a.

BRASIL. Projeções do Agronegócio. Brasil 2014/15 a 2024/25. Projeções de longo prazo. Brasília: MAPA, 2015b. Disponível em: $<$ http://www.agricultura.gov.br/arq_editor/PROJECOES_DO_AGRONEGOCIO_2025_WEB.pdf $>$. Acesso em: 28 mar. 2016.

BRENNER, Neil; PECK, Jamie; THEODORE, Nik. Variegated Neoliberalization: Geographies, Modalities, Pathways. Global Networks. Oxford, 10/2, p. 182-222, 2010.

BÜHLER, Eve Anne; OLIVEIRA, Valter Lúcio de. La localisation des entreprises agricoles dans l'ouest de l'état de Bahia au Brésil. Études Rurales, Paris, 191, p. 91-113, 2013.

BULL, Benedicte; AGUILAR-STOEN, Mariel Cristina. Environmental Politics. In: Latin America: Elite dynamics, the left tide and sustainable development. Londres: Routledge, 2014.

CAMARGO, Renata. O ministro da Agricultura pisou no pequi ». UNB Clipping. Disponível em: $<$ http://www.unb.br/noticias/unbagencia/cpmod.php?id=86187>, Acesso em: 20 mars 2016.

CASTREE, Noel. Commodifying what nature? Progress in Human Geography. Manchester, 27/3, p. 273-297, 2003.

CHIAVARI, Joana; LOPES, Cristina Leme. Os caminhos para a regularização ambiental: decifrando o novo código florestal. In: Mudanças no código florestal brasileiro: desafios para a 
implementação da nova lei, dirigé par Ana Paula Moreira da Silva, Henrique Rodrigues Marques \& Regina Helena Rosa Sambuich, 21-44. Rio de Janeiro: IPEA, 2016.

CONTINI, Elisio; GASQUES, José Garcia; ALVES, Eliseu; BASTOS, Eliana Teles. Dinamismo da agricultura brasileira. Revista de política agrícola, Brasília, XIX (Edição Especial de Aniversário do Mapa - 150 anos), p. 42-64, 2010.

DUARTE, Jorge; RODRIGUES, Nadir. Mapeamento inédito mostra uso e cobertura do Cerrado. Embrapa, 2015. Disponível em: <https://www.embrapa.br/busca-de-noticias//noticia/7808194/mapeamento-inedito-mostra-uso-e-cobertura-do-cerrado>. Acesso em: 03 mai. 2017.

DUMOULIN, David Kervran. Les politiques de conservation de la nature au coeur de l'internationalisation et de la convergence des ordres politiques. Revista de la CEPAL. Sélection d'articles 1995-2004. Santiago du Chili - Paris, CEPAL-IHEAL. 71-86, Juin 2005. Disponível em: $<$ http://www.eclac.cl/publicaciones/xml/2/22182/G2263Dumoilin.pdf $>$. Acesso em: 30 set. 2016.

EKERS, Michael; PUDHAM, Scott. Towards the socio-ecological fix. Environment and Planning A. 47, p. 2438-2445, 2015.

FAIRBAIRN, Madeleine. Like gold in yeld: evolving intersections between farmland and finance. The Journal of Peasant Studies, Londres, 41, p.777-795, 2014.

FREDERICO, Samuel. O novo tempo do cerrado: expansão dos fronts agrícolas e controle do sistema de armazenamento de grãos. Tese de Doutorado em Geografia. São Paulo: Universidade de São Paulo, 2009.

FREITAS, Corin de; MARSTON, Andrea J.; BAKKER, Karen. Not-quite-neoliberal natures in Latin America: An introduction. Geoforum, Paris, 64, p. 239-245, 2015.

GAUTREAU, Pierre; GISCLARD, Marie; LANGBEHN, Lorenzo; DUPONT, Gabrielle Marquis. Regular as fronteiras agrícolas sul-americanas? Experiências e negociações ambientais no Chaco argentino, no Uruguai e no Rio Grande do sul - Brasil. In: BÜHLER, Eve Anne; GUIBERT, Martine; OLIVEIRA, Valter Lúcio de. (Orgs.) Agriculturas empresariais e espaços rurais na globalização. Abordagens a partir da América do Sul. Porto Alegre: UFRGS Editora, Série Estudos Rurais, p. 171-192, 2016.

HECHT, Susanna B. Soybeans, Development and Conservation on the Amazon Frontier. Development and Change 36(2), p. 375-404, 2005.

HIGGINS, Vaughan; POTTER, Clive, DIBDEN, Jacqui; COCKLIN, Chris. Editorial. Neoliberalising rural environments. Journal of Rural Studies 36, p. 386-390, 2014.

INEMA. CAR Bahia (CEFIR). Disponível em: <http://www.inema.ba.gov.br/programas/car-bahiacefir/>. Acesso em: 15 set. 2017, 2015.

LE TOURNEAU, François-Michel. Le Brésil maîtrise-t-il (enfin) la déforestation en Amazonie?, Cybergeo : European Journal of Geography, Paris. Environnement, Nature, Paysage, document 753, 10 dezembro, 2015. Disponível em: <http://journals.openedition.org/cybergeo/27325>; DOI: 10.4000/cybergeo.27325. Acesso em: 15 jan. 2018.

LEITE, Sergio Pereira. Politiques publiques et agribusiness: une analyse de la politique de financement agricole actuelle du Brésil. Géographie, économie, société, Cachan, 17(4), p. 433-458, 2015.

LAHSEN, Myanna; BUSTAMANTE, Mercedes M. C.; DALLA-NORA, Eloi L. Undervaluing and Overexploiting the Brazilian Cerrado at Our Peril. Environment: Science and Policy for Sustainable Development, Philadelphia, 58 (6), p. 4-15, 2016.

MARCH, Hug. Neoliberalismo y medio ambiente : una aproximacion desde la geografía crítica. Documents d'anàlisi geogràfica. Barcelona, 59/1, p. 137-153, 2013. 
MINISTÉRIO do Meio Ambiente. Os planos de controle e prevenção do desmatamento em âmbito Federal, 2017. Disponível em: <http://combateaodesmatamento.mma.gov.br/" http://combateaodesmatamento.mma.gov.br/>. Acesso em: 10 jun. 2017.

MORAES, Maria Dione C. Um povo do Cerrado entre baixões e chapadas (modo de vida e crise ecológica de camponeses/as nos cerrados do sudoeste piauiense. In História Social do Campesinato Brasileiro, Vol. II coord.: Godoi E.P.; Menezes; Marin R.A. 131-162. São Paulo: Editora da UNESP, 2009.

MOREIRA, Eliane. $O C A R$ : a nova face da grilagem na Amazônia. 2016. Disponível em: $<$ https://www.abrampa.org.br/site/?ct=noticia\&id=230"

https://www.abrampa.org.br/site/?ct=noticia\&id=230>. Acesso em: 10 jun. 2017.

OUMA, Stefan. Situating global finance in the land rush debate : a critical review. Geoforum 57, p. 162-165, 2014.

PIRES, Victor. Os desafios da regularização ambiental depois do CAR. 2017 Disponível em: $<$ https://www.socioambiental.org/pt-br/noticias-socioambientais/os-desafios-da-regularizacaoambiental-depois-do-car" https://www.socioambiental.org/pt-br/noticias-socioambientais/osdesafios-da-regularizacao-ambiental-depois-do-car>. Acesso em: 07 out. 2017.

PITTA, Fabio; MENDONÇA, Maria Luiza. A empresa RADAR S/A e a especulação com terras no Brasil. Rede Social de Justiça e Direitos Humanos. São Paulo: Outras expressões, 2015. Disponível em: $<\mathrm{http}: / / w w w . s o c i a l . o r g . b r / f i l e s / p d f / R e v i s t a R E D E 2015$ paranet\%202.pdf" http://www.social.org.br/files/pdf/RevistaREDE2015paranet\%202.pdf>. Acesso em: 15 mai 2017.

REIS, Alessandra Terezinha Chaves Cotrim. Cartilha sobre regularização ambiental de propriedades rurais na Bahia. Barreiras-BA: AIBA, 2016.

ROMERO, Simon. TIAA-CREF, U.S. Investment Giant, Accused of Land Grabs in Brazil. New York Times, New York 16 nov. 2015. Disponível em: $<$ https://www.nytimes.com/2015/11/17/world/americas/tiaa-cref-us-investment-giant-accused-ofland-grabs-in-brazil.html" https:/www.nytimes.com/2015/11/17/world/americas/tiaa-cref-usinvestment-giant-accused-of-land-grabs-in-brazil.html>. Acesso em: 05 out. 2017.

ROSA, Thais Freitas. L'agrobusiness brésilien en quête de durabilité. Une évaluation du « Plan ABC ». Mémoire de Recherche. Master en Géographie des Pays Emergents et en Développement. Paris: Université Paris 1 - Panthéon Sorbonne, 2017.

SABAI, Ernani Edivino. Panorama socioeconômico do agronegócio do oeste da Bahia, BarreirasBA: AIBA [online], 2015. Disponível em: <http:/aiba.org.br/wpcontent/uploads/2013/11/producao-e-destino-dos-graos-do-oeste-da-bahia.pdf $>$. Acesso em: 05 abr. 2016

SVAMPA, Maristella. Consenso de los commodities, giro ecoterritorial y pensamiento crítico en América Latina. Observatorio Social de América Latina, Buenos Aires, ano XIII 32: 15-38, 2012.

WESZ Junior, Valdemar João. O mercado da soja e as relações de troca entre produtores rurais $e$ empresas no Sudeste de Mato Grosso (Brasil). Tese de doutorado em Ciencias Sociais em Desenvolvimento, Agricultura e Sociedade. Rio de Janeiro: Universidade Federal Rural do Rio de Janeiro, 2014. Disponível em: $<$ http://campohoje.net.br/sites/default/files/acervo/Wesz_Jr_Tese_2014.pdf" http://campohoje.net.br/sites/default/files/acervo/Wesz $\overline{\mathrm{J} r} \overline{\mathrm{T}}$ ese_2014.pdf>. Acesso em: 29 juillet 2017. 